\author{
35540 \\ THE DOW CHEMICAL COMPANY \\ ROCKY FLATS DIVISION \\ DENVER, COLORADO
}

U. S. Atomic Energy Commission Contract AT(29-1)-1106

\title{
RADIOACTIVE FILTER BANK FIRE DETECTION SYSTEMS
}

by

R. W. Walker

Facsimile Price $\$ 1,60$
Microfilm Price $\$ 180$
Available from the
Office of Technical Services
Department of Commerce
Washington 25, D. C.

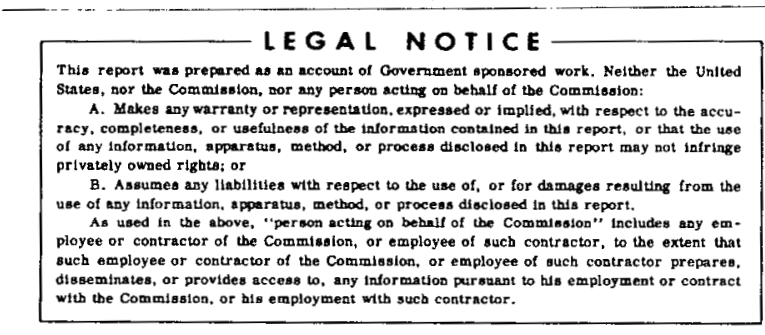

December 27, 1961

December

in the open literatumitted for publication

prior to the issuance at least 6 months

card. Since the ance date of this Mich

dence that it has been publis has no evi-

per is being distributed in

form as a preprint.
. 


\section{DISCLAIMER}

This report was prepared as an account of work sponsored by an agency of the United States Government. Neither the United States Government nor any agency Thereof, nor any of their employees, makes any warranty, express or implied, or assumes any legal liability or responsibility for the accuracy, completeness, or usefulness of any information, apparatus, product, or process disclosed, or represents that its use would not infringe privately owned rights. Reference herein to any specific commercial product, process, or service by trade name, trademark, manufacturer, or otherwise does not necessarily constitute or imply its endorsement, recommendation, or favoring by the United States Government or any agency thereof. The views and opinions of authors expressed herein do not necessarily state or reflect those of the United States Government or any agency thereof. 


\section{DISCLAIMER}

Portions of this document may be illegible in electronic image products. Images are produced from the best available original document. 
Title:

Systems

Author:

Organization:
Radioactive Filter Bank Fire Detection

R. W. Wa lker

Rocky Flats Division, The Dow Chemical Company, Denver, Colorado

Work done under AEC Contract AT(29-1)-1106 
Several fires during the past five years or so have pointed up the need for both fire detection and protection, and have established the fact that installations are definitely vulnerable to fires. An incident in a main exhaust air filter bank at the U. S. Atomic Energy Commission facility, Rocky Flats, Colorado, showed that the integrity of a multi-million dollar facility could be jeopardized by the lack of adequate fire detection and protection. This article deals mainly with the detection of radioactive filter fires.

Filters are used in main building exhaust filter bank plenums as well as in equipment drybox recirculating systems. Although they may be of the fire resistant type, they contain variable amounts of combustible materials due to dust, lint, and other materials which are filtered out. Fires originating ahead of these filters could produce sparks or hot particles which would be carried through duct systems and could set filters on fire. A number of actual tests of burning filters were conducted, using different types of fire detection systems. As a result of these tests, criteria requirements for a suitable filter fire detection system were established as follows :

1. Rugged in construction.

2. Reasonably fast in response.

3. Repeatable in performance at the specified detection setting after a fire.

4. Self-resetting after a fire. 
5. Free from false alarms.

6. Easy to maintain.

7. All circuits suitably supervised.

After the incident of the filter bank fire at the Rocky Flats Division (Fig. 1), the following specific criteria was set forth for the detection and protection of the filter banks at Rocky Flats, all of which meets the above general requirements:

1. Install a fire detection system that will automatically perform the following operations:

A. Activate the water spray system described in item 2 below.

B. Transmit an alarm to the fire station.

C. Give visual and audible signals to the building engineer and building superintendent.

D. Give a local alarm and a remote alarm in the dispatch headquarters in case of trouble in the system.

2. Install in the filter plenums, a fire protection system consisting of water spray systems of the deluge type, which are to be actuated automatically by a detection system and which can also be turned on and off manually.

Considerable engineering and testing time was spent in investigating the market for an applicable fire detection system. Of the systems checked for meeting the above requirements; all were lacking in at least one of the seven requirements. It was not until after looking into the fire detection systems used on aircraft that a system potentially meeting all the above requirements was found. To confirm the applicability of the aircraft type systems 
for this application, extensive tests were performed under simulated filter fire conditions in a test filter plenum (Figs. 2 \& 3). Also included with the above test was a rate-of-rise tubing system, which was presently being used in the filter plenums, and a smoke type detection system.

All of the above sensing element detectors were strung across the center face of each filter (Fig. 4), mounted on brackets approximately six inches from the face of the filters as in a regular filter bank. Of course, with the exception of the smoke detector, the sampling point for this system was installed at the inlet to the exhaust fan. Fan speeds and air flow values were simulated. Temperature recordings were taken at the sensing elements opposite tre point where the fires were started as well as at other chosen points. A water spray system was installed on both sides of the filters for automatic activation by one of the detection systems as we11 as by manual operation. The detector systems were tested with both flames from burning filters and water spray, which heated and cooled the sensing elements under severe conditions.

Some thirty-nine (39) different tests were performed, which gave test data for plotting curves, graphs and tables to help in making as accurate an evaluation as possible. Table I and Fig. 5 show some of the test data in general form used in making these evaluations. From these tests, and to meet specific requirements for Rocky Flats installations, the 
rate-of-rise tubing was shown not to be applicable for this type application, due to the possibility of false alarms. Smoke stratification, location of smoke being filtered from process waste incinerators, and the required number of detectors, could cause false alarms and the wetting down of many filters in exhaust filter plenums. This could cause a great expense in filter replacement and possible radioactive contamination to surrounding areas. However, smoke type detectors could definitely serve in a detection system of this type for giving pre-alarms to alert supervisory building personnel of the possible presence of a fire.

of the two aircraft type systems tested, both proved to be satisfactory in meeting the above seven requirements, except for a few problems not related to the systems involved. Of the relatively large number of fire tests on the aircraft type systems and at temperatures in excess of $1000 \mathrm{~F}$ (Fig. 6), these systems performed well in meeting the above seven requirements.

After careful consideration, a discrete eutectic salt type continuous fire detection (CFD) 255 F tubing system as manufactured by Fenwal. Inc., was chosen to be used for fire detection on the filter bank systems. The detection tubing has an outer tube of Inconel (0.088-in. OD), is packed with a thermally sensitive eutectic salt compound and a nickel wire center conductor. This tubing is available in various temperature settings from $255 \mathrm{~F}$ to $1200 \mathrm{~F}$. An 
overheat at any point along the tubing causes a short between the Inconel and the center conductor, which is sensed by a control unit and in turn to a control panel, which automatically performs the required functions (Fig. 7) and remains energized until the overheat condition is corrected.

The above CFD system is presently installed on all of the filter bank systems at the Rocky Flats Plant. In buildings where combustible type filters are used, the tubing is strung across the face of each horizontal row of filters. Where the fire resistant type filters are used, the tubing is strung across the face of every other horizontal row of filters (Fig. 8). Each circuit of tubing is a maximum of 150 feet in length and each circuit is connected to a CFD control unit which, upon detection of a fire, sends a signal to the control panel for that particular detection system. The control panel in turn actuates the required functions (Fig. 7), such as fire alarms and spray system. The control panel is supervised to give a local trouble alarm and a trouble alarm at dispatch headquarters. The supervisory circuit will give a trouble alarm and light in the event that power fails, an open circuit occurs in any of the detector loops or auxiliary circuits (including circuits to sprinklers, alarm devices and automatic fire stations), a short-circuit or ground develops which might cause the system to fail to operate or cause a false alarm, or if the control cabinet is opened. Silencing buttons, test switches and pilot lights are provided on the control panel for silencing trouble and local 
alarms, for testing the system and for giving visual indications of the condition: of the system.

Although these systems have been in operation for approximately one year, anactual incident has not been experienced on any of these filter bank detection systems. Periodic heat tests are applied to the detector tubing circuits to check the complete operations of the detection systems. With periodic testing, these CFD:systems should readily detect a fire, perform the required functions and give a sense of assurance of adequate fire detection and protection.

Bibliography Don J. Keigher, "Badioactive Filter Design Fire Problems". Fire Protection Engineer, Hanford Operations Office, U. S. Atomic Energy Commission : Quarterly: of the NFPA Voli. 52 , July 1958

Gilbert Humphrey, James: H: Palmer, "High Efficiency Particulate Air. Filter Units". USAEC Report TID:-7023; August 1961, (Unclassified): 

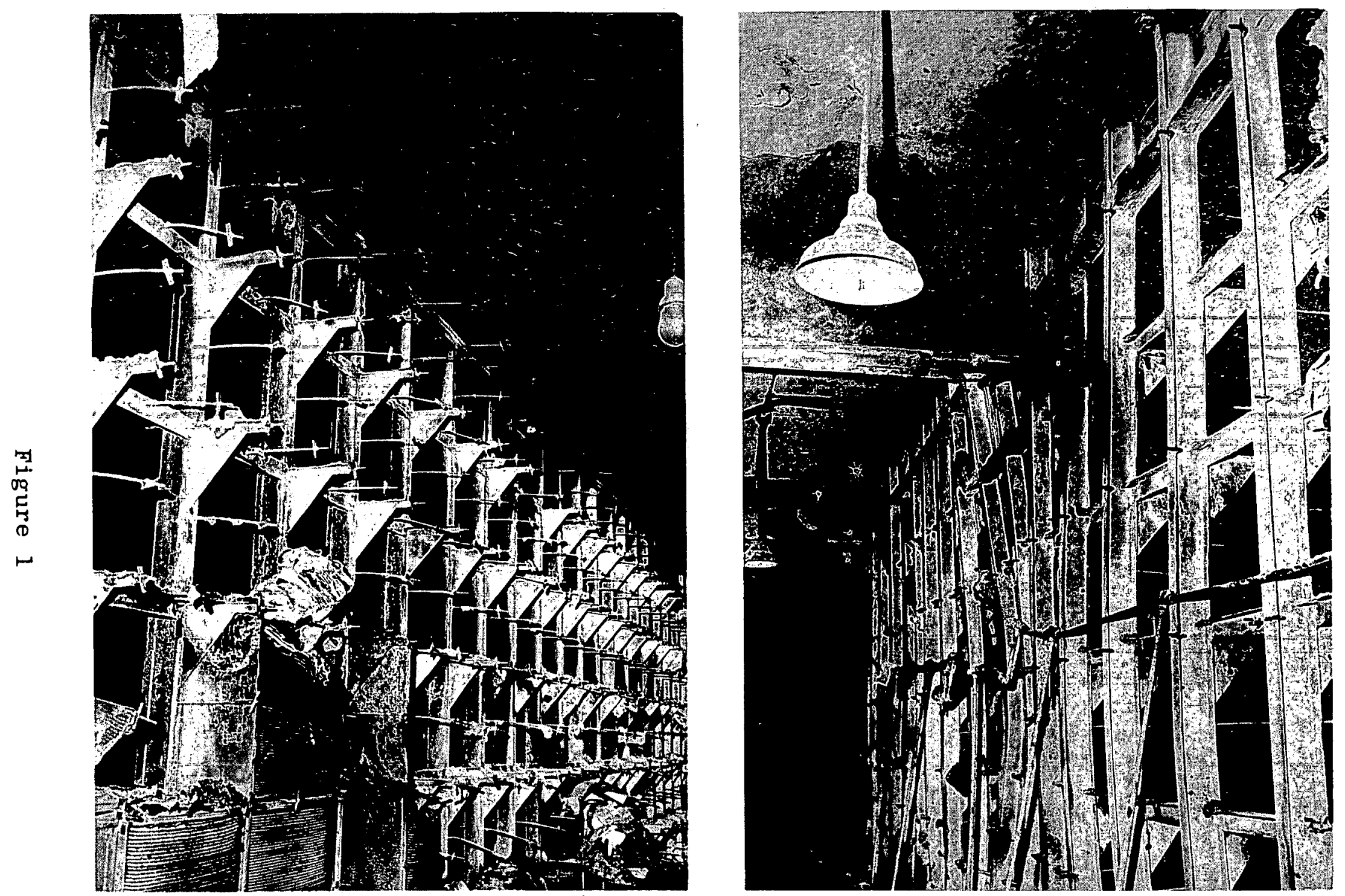

Two views of fire damage to a large bank of filters. This bank located in a fire-resistive room, had the combustible CWS type filters and once involved in fire was most difficult to control. Note filter fasteners, warped steel work and spalled concrete. Cleanup \& decontamination was a dirty and difficult task. 



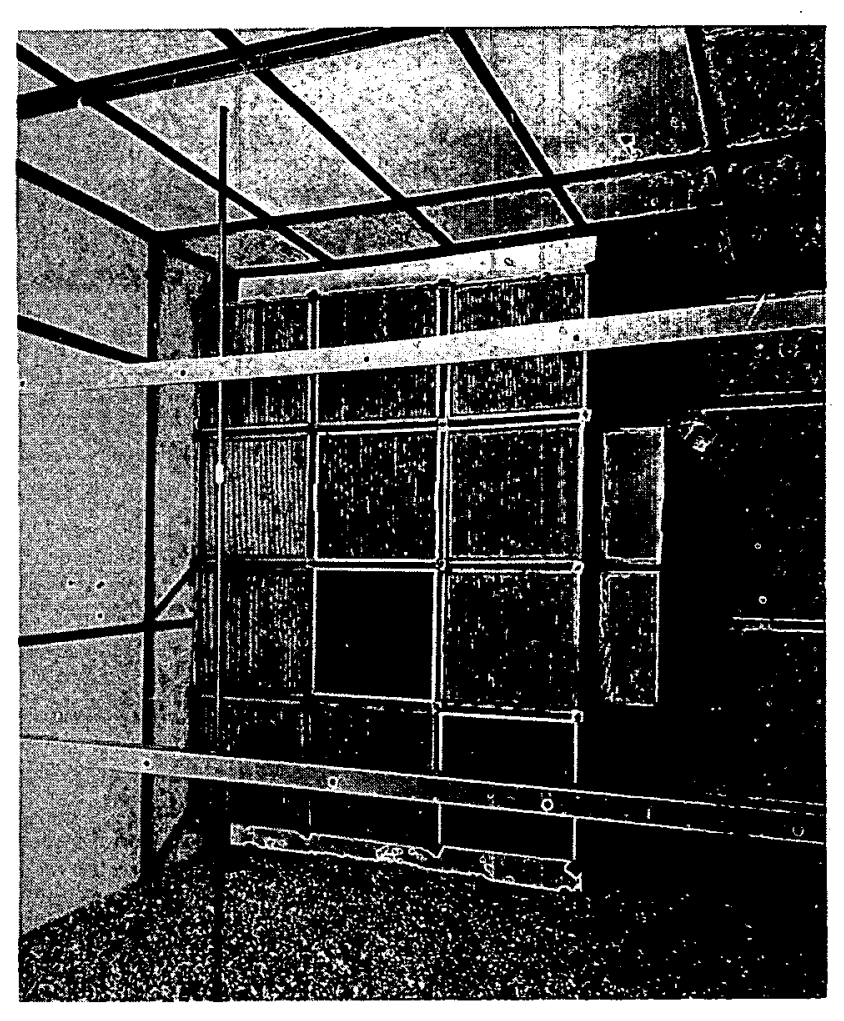



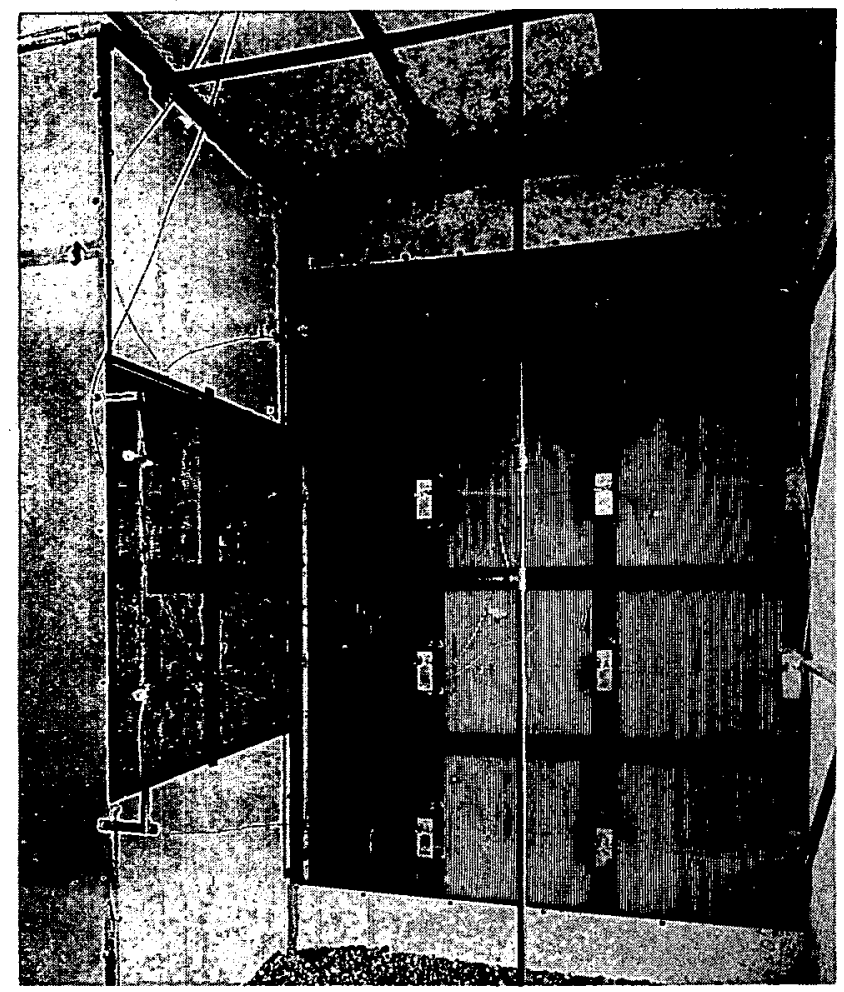




AVERAGE ALARM TIME IN SECONDS

AF TER IGNITION

\begin{tabular}{|c|c|c|c|c|c|}
\hline \multirow{2}{*}{$\begin{array}{c}\text { Fan } \\
\text { Spoed }\end{array}$} & \multirow{2}{*}{$\begin{array}{c}\text { Firo } \\
\text { Brootiney }\end{array}$} & \multirow{2}{*}{$\begin{array}{l}\text { Smoke } \\
\text { Dafector }\end{array}$} & \multicolumn{2}{|c|}{ Arcroll Type Delector } & \multirow{2}{*}{$\begin{array}{l}\text { Coppor } \\
\text { Tubing }\end{array}$} \\
\hline & & & Trpo A & TYpe $\mathbf{B}$ & \\
\hline Low & 106 & 22 & 64 & 99 & 100 \\
\hline odium & 98 & 22 & 01 & 95 & 98 \\
\hline High & 76 & 20 & 82 & 89 & 80 \\
\hline
\end{tabular}

$\underline{T A B L E-1}$

AVERAGE RUN TEPAPERATURES \& ALARM TIMES

AT PAEDIUAA AIR FLOW

(AVERAGE OF (2 RUNS)

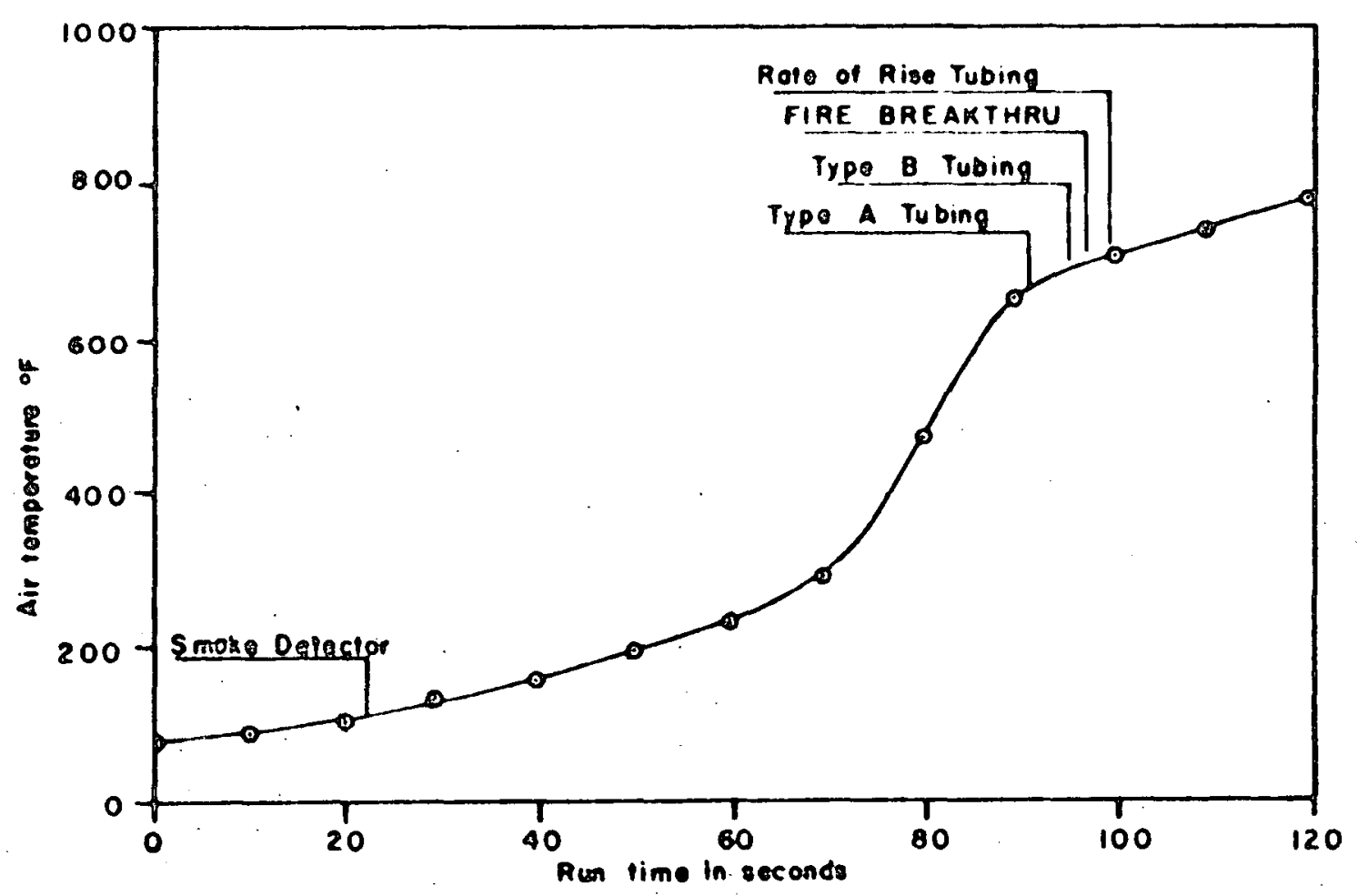

FIGURE - 5 


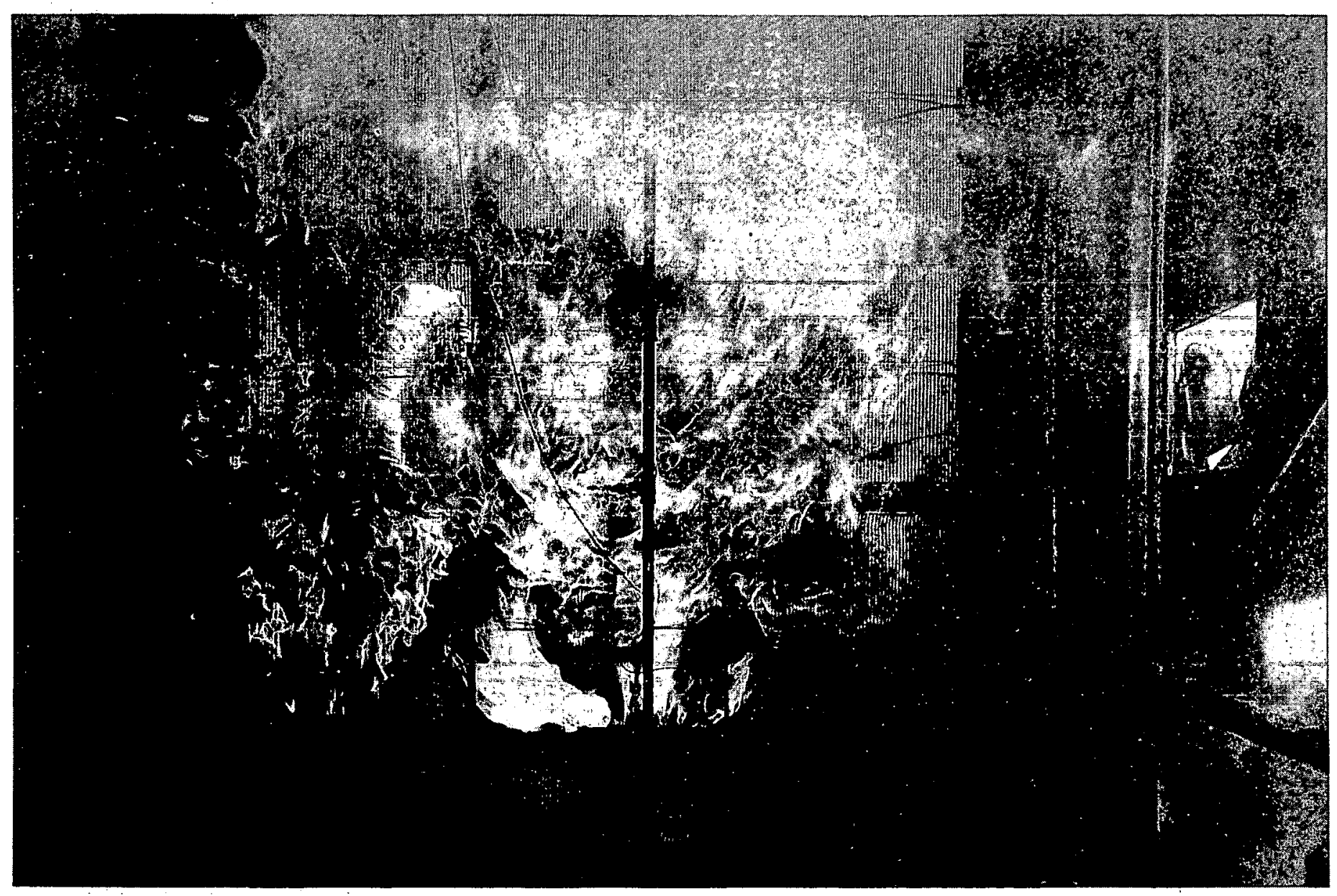

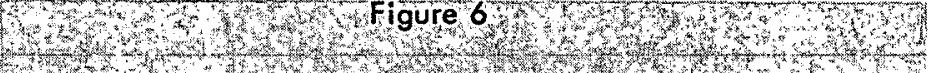

The obove view shows the downstream side of one of the filter burning tests in testing the various types of fire detection systems used. 


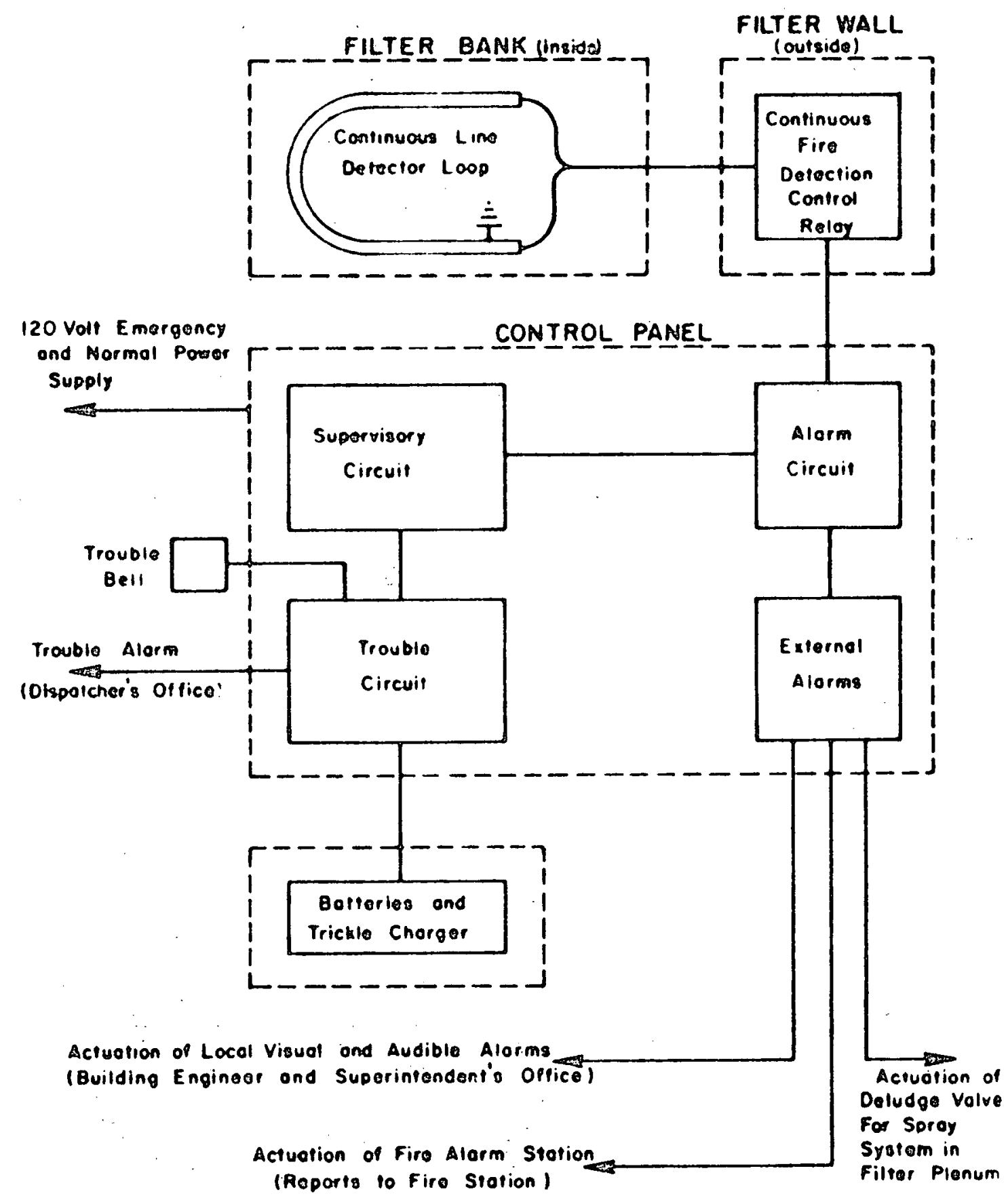

FIGURE - 7

TYPICAI. FENWAL FIRE DETECTION SYSTEM

BOX DIAGRAM 


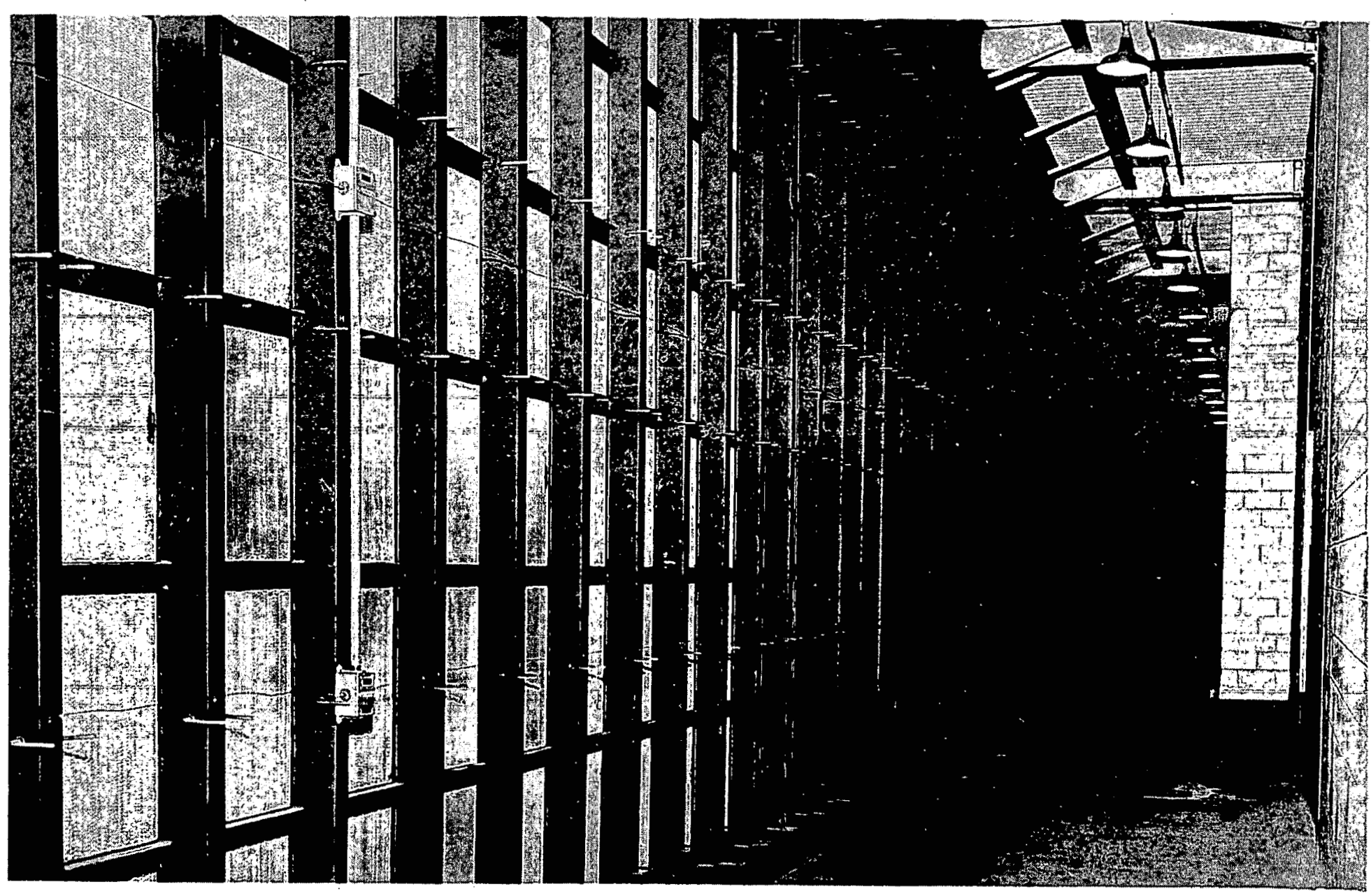

Figure 8

View showing the CFD detection tubing presently installed on a large bank of filters. 